\title{
Ctenus similis F.O. Pickard-Cambridge, a poorly known ctenid spider from Amazonian Forest (Araneae, Ctenidae, Cteninae)
}

\author{
Daniele Polotow \& Antonio D. Brescovit
}

Laboratório de Artrópodes, Instituto Butantan. Avenida Vital Brasil 1500, 05503-900 São Paulo, São Paulo, Brasil. E-mail: adbresc@terra.com.br; danielepolotow@yahoo.com.br.

\begin{abstract}
The female of Ctenus similis F.O. Pickard-Cambridge is redescribed and the male described for the first time. The geographic distribution of the species is extended to Juruti, Pará, Brazil. KEY WORDS. Brazil; neotropical region; taxonomy.

RESUMO. Ctenus similis F. O. Pickard-Cambridge, uma aranha pouco conhecida da Floresta Amazônica (Araneae, Ctenidae, Cteninae). A fêmea de Ctenus similis F.O. Pickard-Cambridge é redescrita e o macho é descrito pela primeira vez. Sua distribuição geográfica é ampliada para Juruti, Pará, Brasil.

PALAVRAS-CHAVE. Brasil; região neotropical; taxonomia.
\end{abstract}

Ctenus similis was described by Pickard-CAmbridge (1897) based on a single female collected in Santarém, state of Pará, Brazil. EIскSTEDT (1981b) presented a redescription of the type material and illustrated the external epigynum. According to EICKSTEDT (1981b), only the type-species was recorded in collections and the specimen listed as C. similis by MeLLo-Leitão (1949: 11) was a misidentification. Later, this specimen was described as Ctenus carvalhoi (EICKSTEDT 1981a).

Recently, collecting expeditions in the Platô do Rio Juruti, Juruti, state of Pará, Brazil, resulted in several specimens identified as Ctenus similis, allowing the identification of the male and expanding the distribution range of the species.

In this paper the female of Ctenus similis F. O. PickardCambridge is redescribed and the male described for the first time. The geographic distribution of the species is extended to Juruti, Pará, Brazil.

The material examined is deposited in Museu Paraense Emílio Goeldi, Pará (MPEG, A.B. Bonaldo) and Instituto Butantan, São Paulo (IBSP, A.D. Brescovit). All measurements are in millimeters. Terminology follow PoLotow et al. (2005). The epigynum was detached from the abdomen and submerged in clove oil for examination of the internal structures. Abbreviations: (ALE) anterior lateral eyes, (AME) anterior median eyes, (p) prolateral, (PLE) posterior lateral eyes, (PME) posterior median eyes, (r) retrolateral, (RTA) retrolateral tibial apophysis, (v) ventral.

\section{Ctenus similis F.O. Pickard-Cambridge, 1897}

Figs 1-11

Ctenus similis F.O. Pickard-Cambridge, 1897: 55, 77 and 83, pl. 3, figs 1c and 4a (Female holotype from Santarém, Pará, Brazil, 13.XII.1896, E.E. Austen leg., BMNH 102, examined); F.O. Pickard-Cambridge, 1902: 411, 413; Petrunkevitch,
1911: 477; Mello-Leitão, 1936: 4, 13; Eickstedt, 1981b: 172173, figs 1 and 4; Platnick, 2007.

Diagnosis. Ctenus similis is distinguished from the other Ctenus species of the Amazonian Forest (HöFer et al. 1994) by the metatarsi II and III with modified ventral bristles, with globular base (Fig. 6), elongated median apophysis, with a longitudinal laminar process in the concave surface (only visible on the expanded palp), a conical retrolateral projection on tegulum and by a retrolateral, truncated and slightly sclerotized projection in cymbium (Figs 7-8) in the male palp. The females are distinguished from the other Ctenus species of the Amazonian Forest (HöFer et al. 1994) by the median field strongly excavated anteriorly, the copulatory openings positioned in the excavated border of the median field (Figs 9-10) and by the median field ventrally projected (Fig. 11) in the epigynum.

Description. Male (MPEG 389). Carapace, chelicerae, endites, labium, sternum and legs reddish brown; carapace with light brown border and longitudinal light brown stripe from the eye area to the posterior border; abdomen brown, with a dorsal lighter brown arrow. Total length 8.10. Carapace 4.60 long, 3.70 wide. Chelicerae: with three promarginal teeth and four retromarginal teeth, with a row of small teeth between the promarginal and the retromarginal teeth (Fig. 1). Clypeus 0.18 high. Eye diameters: AME 0.21, PME 0.22, ALE 0.16 and PLE 0.20. Leg measurements: I: femur 4.30/patella 2.00/tibia 4.20/metatarsus 3.90/tarsus 1.80/total 16.20; II: 3.80/1.80/3.20/ 3.30/1.50/13.60; III: 3.40/1.50/2.60/3.60/1.30/12.40; IV: 4.50/ 1.70/3.90/5.60/1.90/17.60. Leg formula: 4132. Leg spination: tibia I v2-2-2-2-2, p0-1-0, r1-1-0, II v2-2-2-2-2, p1-0, r1-0, III-IV v2-2-2, p1-1, r1-1, metatarsus I-II v2-2-2, p1-1-1, r1-1-1, III v22-2, p1-1-1, r1-1-1, IV v1-1-1-1-1-2, 1-1-1, r1-1-1. Tarsal organ rounded and smooth, with oval aperture (Fig. 4). Trichobothrial 

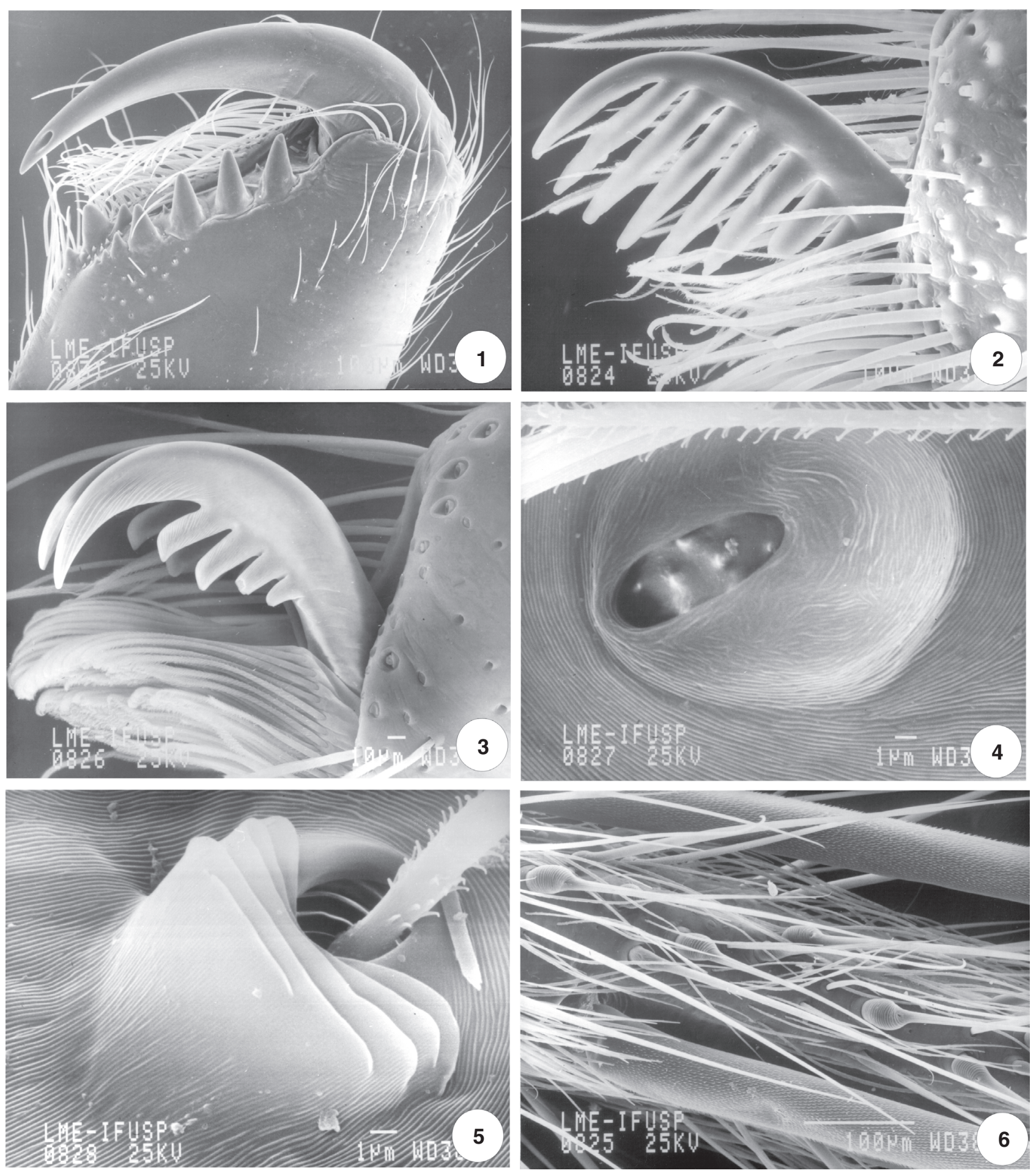

Figures 1-6 Ctenus similis: (1) male chelicerae; (2) female pedipalp claw; (3) male claw of leg l; (4) tarsal organ; (5) trichobotria; (6) male metatarsi III, ventral view.

Revista Brasileira de Zoologia 24 (3): 587-590, setembro 2007 

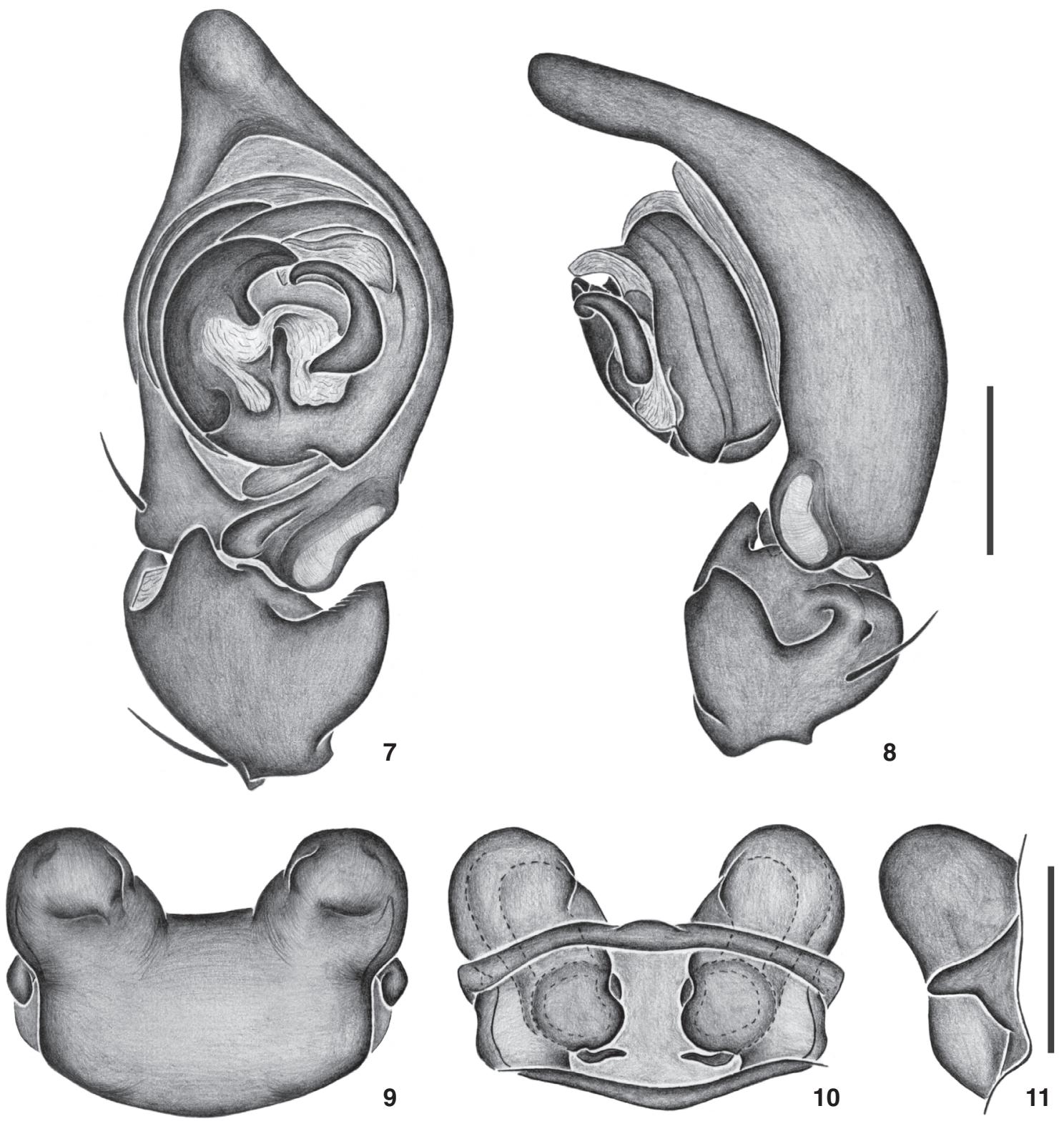

Figures 7-11 Ctenus similis: (7) male left palp, ventral view; (8) male left palp, retrolateral view; (9) epigynum, ventral view; (10) epigynum, dorsal view; (11) epigynum, lateral view. Scales bars: $0.50 \mathrm{~mm}$.

base with 4 to 5 transversal grooves (Fig. 5). Trochanters I-IV notched. Palp: tibia short, aproximately half the cymbium length; RTA short and robust, divided into a large ventral branch pointed at the apex and a rounded and truncated dorsal branch, with an internal depression and a rounded dorsal projection (Fig. 8); cymbium elongated, with a truncated and slightly sclerotized retrolateral projection; subtegulum elongated (Fig. 7); tegulum rounded with a conical retrolateral projection (Figs 78); embolus curved, large and smooth (Fig. 7); median apo- physis curved and narrow, with retrolateral surface convex and prolateral surface concave (Fig. 7); median apophysis with a longitudinal laminar process in the convave surface (only visible on the expanded palp); conductor laminar and hyaline, not envolving the tip of the embolus (Fig. 7).

Female (MPEG 388). Coloration pattern as in male. Total length 10.60. Carapace 4.60 long, 3.40 wide. Clypeus 0.24 high. Eye diameters: AME 0.22, PME 0.24, ALE 0.18 and PLE 0.22. Pedipalp claw slender, with seven elongated teeth (Fig. 2). Leg

Revista Brasileira de Zoologia 24 (3): 587-590, setembro 2007 
measurements: I: femur 3.70/patella 1.80/tibia 3.30/metatarsus 2.90/tarsus 1.30/total 13.00; II: 3.30/1.70/2.80/2.60/1.20/ 11.60; III: 3.10/1.40/2.40/2.80/1.20/10.90; IV: 3.90/1.50/3.50/ 4.20/1.50/14.60. Leg formula: 4132. Leg spination as in male, except: tibia I-II p0, r0 and metatarsus I-II p0, r0. Trochanters I-IV notched. Epyginum: externally with a large median field strongly excavated anteriorly (Fig. 9) and ventrally projected (Fig. 11); lateral fields with short lateral spurs positioned medially (Fig. 9); copulatory openings positioned in the excavated border of the median field; internally with copulatory ducts large and covering the rounded spermathecae (in dorsal view) (Fig. 10); fertilization ducts short, slender and positioned at the base of spermatheca (Fig. 10).

Variation. Ten males: total length 6.70-9.50, carapace 3.80-5.80, femur I 3.50-5.20. Ten females: total length 8.7011.70, carapace 3.90-5.60, femur I 3.00-4.50.

Material examined. Brazil, Pará: Juruti (platô do Rio Juruti, $\left.02^{\circ} 33^{\prime} 07,2^{\prime \prime} \mathrm{S}, 56^{\circ} 13^{\prime} 06,2^{\prime \prime} \mathrm{W}\right), 3$ males and 2 females, 4 12.IX.2002, A.B. Bonaldo et al. leg. (MPEG 375, 376, 381, 388); 1 male and 1 female, 11-16.IX.2002, A.B. Bonaldo et al. leg. (MPEG 386 and 389); 1 male, 7.IX.2002, A.B. Bonaldo leg. (MPEG 2284); 3 males and 1 female, 12.IX.2002, A.B. Bonaldo leg. (MPEG 2287); 1 male and 1 female, 15.IX.2002, A.B. Bonaldo leg. (IBSP 70964); 1 male and 1 female, 7.IX.2002, D.D. Guimarães leg. (IBSP 70965); 3 females, 12.IX.2002, D.D. Guimarães leg. (MPEG 373); (platô do Rio Juruti, Igarapé Mutum, 02³6'45,2”S, 56²1'27,5”W) 1 male, 5.IX.2002, D. D. Guimarães leg. (MPEG 387); 3 males, 5.IX.2002, A.B. Bonaldo leg. (MPEG 2283); 1 female, 9.IX.2002, A. B. Bonaldo leg. (MPEG 2286); (Igarapé Mutum, 02³6'11,2”S, $\left.56^{\circ} 12^{\prime} 36,3^{\prime \prime} \mathrm{W}\right), 2$ males, 4.VIII.2004, D.R.S. de Souza leg. (MPEG 1748, 1749); 1 female, 4.VIII.2004, D.F. Candiani leg. (MPEG 1750); Santarém (Alter do Chão), 2 females, 26.I.1999, H. Höfer \& A.D. Brescovit leg. (IBSP 56646).

Distribution. State of Pará, north of Brazil.

\section{ACKNOWLEDGEMENTS}

We wish to thank Cristina A. Rheims, and the two anonymous reviewers for helpful suggestions on the manuscript and Prof. Pedro Kyohara and Miss Simone Perche Toledo for making the scanning electron micrographs. This study was supported by CNPq (Conselho Nacional de Desenvolvimento Ciêntifico e Tecnológico) and FAPESP (Fundação de Amparo à
Pesquisa do Estado de São Paulo, grant nos. 99/05446-8 and 06/55230-7). This study is part of the BIOTA/FAPESP - The Biodiversity Virtual Institute Program (www.biotasp.org.br).

\section{REFERENCES}

EICKSTEDT, V.R.D. von. 1981a. Aranhas do gênero Ctenus coletadas na foz do Rio Culuene, Xingu, Brasil: descrição de uma espécie nova e redescrição de Ctenus villasboasi Mello-Leitão (Araneae; Ctenidae). Memórias do Instituto Butantan 44/ 45: 161-169.

EICKSTEDT, V.R.D. von. 1981b. Redescrição dos tipos de Ctenus similis, Ctenus albofasciatus e Ctenus minor (Araneae; Ctenidae). Memórias do Instituto Butantan 44/45: 171-179.

Höfer, H.; A.D. Brescovit \& T. GaSNIER. 1994. The wandering spiders of the genus Ctenus (Ctenidae, Araneae) of Reserva Ducke, a rainforest reserve in central Amazonia. Andrias 13: 81-98.

Mello-Leitão, C.F. DE. 1936. Contribution à l'etude des Ctenides du Bresil. Festschrift für Strand 1: 1-31.

Mello-Leitão, C.F. DE. 1949. Aranhas da Foz do Kuluene. Boletim do Museu Nacional do Rio de Janeiro 92: 1-19.

Petrunkevitch, A. 1911. A synonymic index-catalogue of spiders of North, Central and South America with all adjacent islands, Greenland, Bermuda, West Indies, Terra del Fuego, Galapagos, etc. Bulletin of the American Museum of Natural History 29: 1-791.

Pickard-Cambridge, F.O. 1897. On Cteniform spiders from the lower Amazons and others regions of North and South America, with list of all known species of these groups hitherto recorded from the New World. The Annals and Magazine of Natural History 19 (7): 52-106.

Pickard-Cambridge, F.O. 1902. New species of spiders belonging to the genus Ctenus, with supplementary notes. The Annals and Magazine of Natural History 9 (7): 401-415.

Platnick, N.I. 2006. The world spider catalog, version 7.5. American Museum of Natural History, available in the World Wide Web at: http://research.amnh.org/entomology/ spiders/catalog/index.html [Accessed in 02.III.2007]

Polotow, D.; A.D. Brescovit \& F. Pellegatti-Franco. 2005. A redescription of Isoctenus coxalis (F. O. P.-Cambridge, 1902) comb. nov. and description of I. corymbus, a new species of cave dwelling spider (Araneae, Ctenidae, Cteninae) from the State of Goiás, Brazil. Revista Ibérica de Aracnologia 11: 37-42.

Received in 06.III.2006; accepted in 20.VII.2007. 